\title{
Oxidative Damage of DNA Induced by Ferritin and Hydrogen Peroxide
}

\author{
Jung Hoon Kang \\ Department of Genetic Engineering, Cheongju University, Cheongju 360-764, Korea. E-mail: jhkang@cju.ac.kr \\ Received July 7, 2010, Accepted August 23, 2010
}

\begin{abstract}
Excess free iron generates oxidative stress that may contribute to the pathogenesis of various causes of neurodegenerative diseases. Previous studies have shown that one of the primary causes of increased brain iron may be the release of excess iron from intracellular iron storage molecules. In this study, we attempted to characterize the oxidative damage of DNA induced by the reaction of ferritin with $\mathrm{H}_{2} \mathrm{O}_{2}$. When DNA was incubated with ferritin and $\mathrm{H}_{2} \mathrm{O}_{2}$, DNA strand breakage increased in a time-dependent manner. Hydroxyl radical scavengers strongly inhibited the ferritin $/ \mathrm{H}_{2} \mathrm{O}_{2}$ system-induced DNA cleavage. We investigated the generation of hydroxyl radical in the reaction of ferritin with $\mathrm{H}_{2} \mathrm{O}_{2}$ using a chromogen, 2,2'-azinobis-(2-ethylbenzthiazoline-6-sulfonate) (ABTS), which reacted with $\cdot \mathrm{OH}$ to form $\mathrm{ABTS}^{+\bullet}$. The initial rate of $\mathrm{ABTS}^{+\bullet}$ formation increased as a function of incubation time. These results suggest that DNA strand breakage is mediated in the reaction of ferritin with $\mathrm{H}_{2} \mathrm{O}_{2}$ via the generation of hydroxyl radicals. The iron-specific chelator, deferoxamine, also inhibited DNA cleavage. Spectrophotometric study using a color reagent showed that the release of iron from $\mathrm{H}_{2} \mathrm{O}_{2}$-treated ferritin increased in a time-dependent manner. Ferritin enhanced mutation of the lac $Z$ gene in the presence of $\mathrm{H}_{2} \mathrm{O}_{2}$ when measured as a loss of $\alpha$-complementation. These results indicate that ferritin $/ \mathrm{H}_{2} \mathrm{O}_{2}$ system-mediated DNA cleavage and mutation may be attributable to hydroxyl radical generation via a Fenton-like reaction of free iron ions released from oxidatively damaged ferritin.
\end{abstract}

Key Words: Ferritin, DNA, Hydroxyl radical, Mutation

\section{Introduction}

Iron is an element essential to cellular metabolism. ${ }^{1}$ As long as iron is bound to ferritin, cytotoxic reactions are not expected. However, when iron is improperly regulated or released from ferritin, it is potentially toxic and can lead to cell death. Iron is one of the most transition metals involved in hydroxyl radical formation, owing to its interaction with hydrogen peroxide through Fenton-type reactions. ${ }^{2}$ Mammalian ferritin is a large, iron-storage heteropolymer composed of two equivalent subunit types, light (FTL) and heavy (FTH) polypeptides, which are expressed in most kinds of cells. ${ }^{3-6}$ Although both types of polypeptide subunit share a high degree of conformational similarity, they play diverse functional roles. The FTH subunit has a potent ferroxidase activity that catalyzes the oxidation of ferrous iron, whereas the FTL subunit plays important roles in iron nucleation and protein stability, giving ferritin the dual functions of iron detoxification and iron storage. ${ }^{3}$

It has been reported that iron can be released from ferritin by various exogenous. ${ }^{7-10}$ and endogenous substances via reductive mechanisms. ${ }^{11,12}$ If iron is released from ferritin, low molecular iron complexes may undergo redox reactions resulting in cytotoxic damage of macromolecules. ${ }^{13,14}$ Oxidants, including $\mathrm{H}_{2} \mathrm{O}_{2}$, have been considered mostly as damaging entities that mediate pathogenic processes. $\mathrm{H}_{2} \mathrm{O}_{2}$ has been implicated in ischemia and reperfusion within the brain, ${ }^{15}$ cancer ${ }^{16}$ and neurodegenerative disease. ${ }^{17}$

This study found that the ferritin/ $\mathrm{H}_{2} \mathrm{O}_{2}$ system resulted in DNA strand breakage. The results indicated that ferritin, as a source of iron, might facilitate oxidative DNA damage.

\section{Experimental Section}

Materials. pUC19 plasmid DNA was prepared and purified from $E$. coli cultures by using QIAGEN plasmid kit (Santa Clarita, USA). Ampicillin, bathophenanthroline sulfonate, deferoxamine and ethidium bromide were purchased from Sigma Chemical Co. (St. Louis, MO). Ferritin was purchased from Calbiochem (Darmstadt, German). The commercial equine spleen ferritin was performed by gel filtration chromatography by using Superose 6 FPLC column (Pharmacia, Sweden) for a further purification. Chelex 100 resin (sodium form) was obtained from Bio-Rad. All solutions were treated with Chelex 100 resin to remove traces of transition metal ions.

Analysis of DNA cleavage. DNA single strand breakages were assayed by measuring the conversion of supercoiled plasmid DNA (form I) to nicked circular DNA (form II) and linear DNA (form III). pUC19 DNA $(0.5-1.0 \mu \mathrm{g})$ in $10 \mathrm{mM}$ potassium phosphate buffer ( $\mathrm{pH} 7.4$ ) was incubated for $3 \mathrm{~h}$ at $37{ }^{\circ} \mathrm{C}$ with different concentrations of $\mathrm{H}_{2} \mathrm{O}_{2}$ and ferritin in a total volume of $20 \mu \mathrm{L}$. The reaction was stopped at $-80{ }^{\circ} \mathrm{C}$. The loading buffer $(0.25 \%$ bromophenolblue, $40 \%$ sucrose $)$ was added and samples analyzed by electrophoresis in $0.8 \%$ agarose in TBE buffer ( $2 \mathrm{mM}$ EDTA, $89 \mathrm{mM}$ boric acid and $89 \mathrm{mM}$ Tris at $\mathrm{pH}$ 8.3). The gel was stained with ethidium bromide. Bands of DNA were detected and photographed under UV light in a dark room.

Measurement of hydroxyl radical. $\cdot \mathrm{OH}$ was measured with a chromogen, 2,2'-azinobis-(2-ethylbenzthiazoline-6-sulfonate) (ABTS). ${ }^{18}$ ABTS is water-soluble and has a strong absorption at $340 \mathrm{~nm}$ with a molar extinction coefficient $\varepsilon_{340}$ of $3.66 \times$ $10^{4} \mathrm{M}^{-1} \mathrm{~cm}^{-1}$. On oxidation, ABTS forms a stable blue-green product presumed to be the cation radical, $\mathrm{ABTS}^{+\bullet}$ is conveniently followed at $\lambda$ max at $415 \mathrm{~nm}\left(\varepsilon_{415}=3.6 \times 10^{4} \mathrm{M}^{-1} \mathrm{~cm}^{-1}\right){ }^{19}$ The assay mixture contained $10 \mathrm{mM}$ potassium phosphate buffer (pH 7.4) and $50 \mu \mathrm{M}$ ABTS and $0.1 \mathrm{mM} \mathrm{H}_{2} \mathrm{O}_{2}$ and $1.0 \mu \mathrm{M}$ protein in a total volume of $1 \mathrm{~mL}$. The reaction was initiated by addition of $\mathrm{H}_{2} \mathrm{O}_{2}$ and the increase in absorbance at $415 \mathrm{~nm}$ was measured with a UV-vis spectrophotometer (Shimazu 1601). 
Determination of free iron concentration. The concentration of iron ions released from oxidatively damaged ferritin was determined by using a bathophenanthroline sulfonate in the method described previously. ${ }^{20}$ The reaction mixture contained $1 \mu \mathrm{M}$ ferritin and $1 \mathrm{mM} \mathrm{H}_{2} \mathrm{O}_{2}$ and a $10 \mathrm{mM}$ potassium phosphate buffer ( $\mathrm{pH} 7.4)$ in a total volume of $0.5 \mathrm{~mL}$. The reaction was incubated for various periods at $37^{\circ} \mathrm{C}$. After the incubation, the mixture was then placed into an Ultrafree-MC filter and centrifuged at 13,000 rpm for $1 \mathrm{~h}$. The colorimetric reagent was added into the filtrate and analyzed by a UV-vis spectrophotometer (Shimadzu, UV-1601) at $535 \mathrm{~nm}$. The final concentrations of the color reagent were $1 \%$ ascorbate, $0.02 \%$ bathophenanthroline sulfonate and 1\% acetic acid-acetate buffer ( $\mathrm{pH} 4.5)$.

Mutagenecity assay. Plasmid DNA was transformed in Escherchia coli $\mathrm{DH} 5 \alpha$ competent cells. The treated plasmid pUC19 carrying the lac $Z$ gene with or without $1 \mu \mathrm{M}$ ferritin and 0.1 $\mathrm{mM} \mathrm{H}_{2} \mathrm{O}_{2}$ was incubated with $50 \mu \mathrm{L}$ of competent cells at $0{ }^{\circ} \mathrm{C}$ for $10 \mathrm{~min}$. SOC medium was added, and the cells were incubated at $37^{\circ} \mathrm{C}$ for $1 \mathrm{~h}$. Transformed cells were spread on LB agar plates containing $0.8 \mathrm{mg}$ of X-gal, $2 \mathrm{mg}$ of IPTG and $0.01 \%$ ampicillin. The plates were inverted and incubated for $24 \mathrm{~h}$ at $37{ }^{\circ} \mathrm{C}$ before counting colonies.

Statistical analysis. Values are expressed as the means \pm S.D of three to five separate experiments. The statistical differences between the means were determined by the Student $t$-test.

\section{Results and Discussions}

When pUC19 DNA was incubated with $0.1 \mathrm{mM} \mathrm{H}_{2} \mathrm{O}_{2}$ or $1 \mu \mathrm{M}$ ferritin alone, it did not cause significant strand breakages (Fig. 1 lanes 1-10). However, a substantial increase in the proportion of nicked circular form (form II) and linear form (form III) occurred with concomitant loss of the supercoiled one (form I) in a time-dependent manner when DNA was incubated in a mixture of $\mathrm{H}_{2} \mathrm{O}_{2}$ and ferritin (Fig. 1, lanes 11-15). This indicates that both ferritin and $\mathrm{H}_{2} \mathrm{O}_{2}$ were required to produce strand breaks in DNA. Deoxyribose and ribose are fragmented by $\cdot \mathrm{OH}$, yielding dozens of products. All positions are susceptible to hydrogen abstraction by $\cdot \mathrm{OH}$, forming carbon radicals. In the presence of $\mathrm{O}_{2}$ these concert rapidly to sugar peroxyl radicals, which undergo a series of reactions including disproportionate,

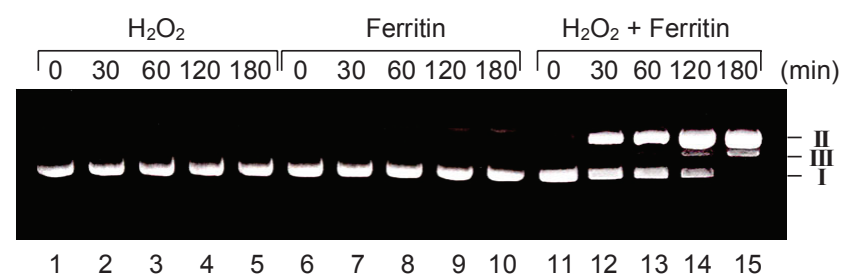

Figure 1. DNA cleavage after incubation with $\mathrm{H}_{2} \mathrm{O}_{2}$ and ferritin. pUC 19 DNA $(1 \mu \mathrm{g})$ was incubated with $\mathrm{H}_{2} \mathrm{O}_{2}$ and ferritin in a $10 \mathrm{mM}$ potassium phosphate buffer $(\mathrm{pH} 7.4)$ at $37^{\circ} \mathrm{C}$ during various incubation periods. The reaction mixture contained $1 \mathrm{mM} \mathrm{H}_{2} \mathrm{O}_{2}$ alone (lane 1-5), $10 \mu \mathrm{M}$ ferritin alone (lane 6-10), $1 \mathrm{mM} \mathrm{H}_{2} \mathrm{O}_{2}$ and $10 \mu \mathrm{M}$ ferritin(lane 11-15). Reaction was stopped by $-80{ }^{\circ} \mathrm{C}$ deep freezing. Loading buffer was added to the samples and analyzed by electrophoresis in $0.8 \%$ agarose. I, II and III indicate the position of the supercoiled, circular and linear DNA plasmid forms, respectively. rearrangement, elimination of water and C-C bond fragmentation, to yield a variety of carbonyl products. Some sugar products remain within DNA or constitute end groups of broken DNA strands, whereas others are released. ${ }^{21}$ It has been reported that $\mathrm{H}_{2} \mathrm{O}_{2}$ generates $\mathrm{ROS}$ through redox cycling that can be facilitated by transition metal ions, such as cooper and iron. ${ }^{2}$ The present result suggested that ferritin might facilitate $\mathrm{H}_{2} \mathrm{O}_{2}$ induced DNA damage.

The role of free radicals in DNA damage caused by the ferritin $/ \mathrm{H}_{2} \mathrm{O}_{2}$ system was studied by examining the protective effect of free radical scavengers. When plasmid DNA was incubated with $\mathrm{H}_{2} \mathrm{O}_{2}$ and ferritin in the presence of azide, formate, mannitol, ethanol, and thiourea at $37^{\circ} \mathrm{C}$ for $3 \mathrm{~h}$, all scavengers significantly prevented DNA cleavage (Fig. 2). The sugar alcohol mannitol, azide and ethanol often used hydroxyl radical scavengers in laboratory experiments, but these scavengers can react with other species of oxygen radicals. ${ }^{2}$ In this study, $\cdot \mathrm{OH}$ generation occurring during the reaction of ferritin with $\mathrm{H}_{2} \mathrm{O}_{2}$ was assessed by using a chromogen, 2,2'-azinobis-(2ethylbenzthiazoline-6-sulfonate) (ABTS), which reacts with .OH to form $\mathrm{ABTS}^{+\cdot} \cdot{ }^{22,23}$ When ABTS was incubated with ferritin and $\mathrm{H}_{2} \mathrm{O}_{2}, \mathrm{ABTS}^{+\bullet}$ formation monitored for $30 \mathrm{~min}$ increased in a time-dependent manner (Fig. 3). However $\mathrm{ABTS}^{+\bullet}$ formation did not occur when ABTS was incubated with $1 \mu \mathrm{M}$ ferritin or $0.1 \mathrm{mM} \mathrm{H}_{2} \mathrm{O}_{2}$ alone. The result suggests that $\cdot \mathrm{OH}$ may participate in the ferritin $/ \mathrm{H}_{2} \mathrm{O}_{2}$-mediated DNA cleavage.

The $\mathrm{H}_{2} \mathrm{O}_{2}$ in vivo is probably a direct product of $\mathrm{O}_{2}{ }^{-}$dismutation and various oxidase reactions. The rates of $\mathrm{H}_{2} \mathrm{O}_{2}$ and $\mathrm{O}_{2}{ }^{-}$formation under physiological conditions have been measured. Considering the volume actually used and the amount of products formed, one obtains a rate $90 \mu \mathrm{M} \mathrm{H}_{2} \mathrm{O}_{2} /$ min in liver ${ }^{24}$ and $340 \mu \mathrm{M} \mathrm{O}_{2}^{-} \cdot / \mathrm{min}$ in glucose fed Escherichia coli cells. ${ }^{25}$ The local concentration of $\mathrm{H}_{2} \mathrm{O}_{2}$ in the immediate vicinity of SOD must be much larger than these values. The production of $\mathrm{O}_{2}{ }^{-}$ will be much larger as the concentration of oxygen increases during exposure to hyperoxia or when the respiratory chain becomes inhibited leading to an increased concentration of reducing equivalents. ${ }^{26}$ Recently it has been reported that hyperoxia induced $\mathrm{H}_{2} \mathrm{O}_{2}$ production increased in human $\mathrm{U} 87$ glioblastoma

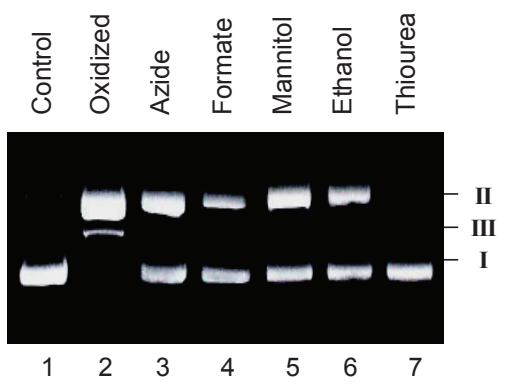

Figure 2. The effect of free radical scavengers on the DNA cleavage by the reaction of ferritin with $\mathrm{H}_{2} \mathrm{O}_{2}$. pUC 19 DNA was incubated with $1 \mathrm{mM} \mathrm{H}_{2} \mathrm{O}_{2}$ and $10 \mu \mathrm{M}$ ferritin in a $10 \mathrm{mM}$ potassium phosphate buffer ( $\mathrm{pH} 7.4$ ) at $37^{\circ} \mathrm{C}$ for $3 \mathrm{~h}$, in the absence and the presence of 20 $\mathrm{mM}$ scavengers at $37^{\circ} \mathrm{C}$. Lane 1, plasmid DNA alone; lane 2, no addition of scavenger; lane 3, azide; lane 4, formate; lane 5, mannitol; lane 6 , ethanol; lane 7, thiourea. Agarose gel electrophoresis was performed in $0.8 \%$ agarose. I, II and III indicate the position of the supercoiled, circular and linear DNA plasmid forms, respectively. 


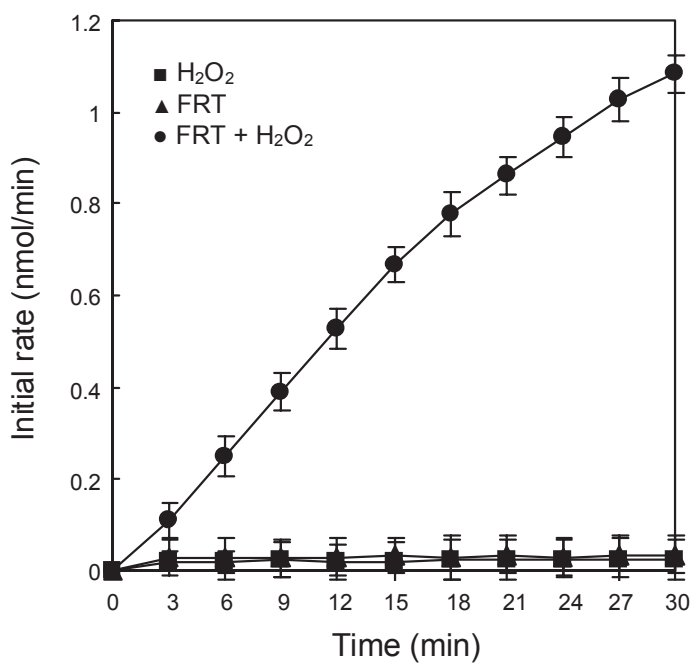

Figure 3. The rates of hydroxyl radical formation determined by using a chromogen, ABTS. $50 \mu \mathrm{M}$ ABTS was incubated with $0.1 \mathrm{mM} \mathrm{H}_{2} \mathrm{O}_{2}$ and $1 \mu \mathrm{M}$ ferritin in a $10 \mathrm{mM}$ potassium phosphate buffer $(\mathrm{pH} 7.4)$ at $37^{\circ} \mathrm{C}$ during various incubation periods. The reaction mixture contained $0.1 \mathrm{mM} \mathrm{H}_{2} \mathrm{O}_{2}$ alone ( $\left.\mathbf{\square}\right), 1 \mu \mathrm{M}$ ferritin alone ( $\left.\mathbf{\Lambda}\right), 0.1 \mathrm{mM} \mathrm{H}_{2} \mathrm{O}_{2}$ and $1 \mu \mathrm{M}$ ferritin $(\bullet)$.

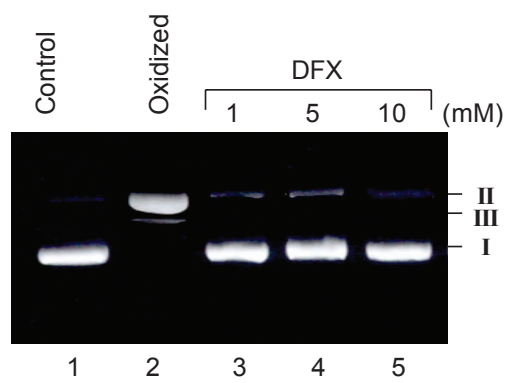

Figure 4. The effect of an iron chelator on the DNA cleavage by the reaction of ferritin with $\mathrm{H}_{2} \mathrm{O}_{2}$. pUC 19 DNA was incubated with $10 \mu \mathrm{M}$ ferritin and $1 \mathrm{mM} \mathrm{H}_{2} \mathrm{O}_{2}$ in potassium phosphate buffer $\left(\mathrm{pH} \mathrm{7.4)}\right.$ at $37^{\circ} \mathrm{C}$ for $3 \mathrm{~h}$ in various concentrations of deferoxamine (DFX). Lane 1, plasmid DNA alone; lane 2, no addition of DFX; lane 3, 1 mM DFX; lane 3, $5 \mathrm{mM}$ DFX; lane 4, $10 \mathrm{mM}$ DFX. Agarose gel electrophoresis was performed in $0.8 \%$ agarose. I, II and III indicate the position of the supercoiled, circular and linear DNA plasmid forms, respectively.

cells. ${ }^{27}$ Thus, at least $0.1 \mathrm{mM} / \mathrm{min} \mathrm{H}_{2} \mathrm{O}_{2}$ will be produced continuously under physiological conditions and at a much higher rate under adverse conditions such as hyperoxia or ischemia and referfusion.

Trace metals such as copper and iron, which are present in biological systems, may interact with hydrogen peroxide, and which causes damage biological molecules including DNA. ${ }^{28-33}$ In cultured cells, raising the level of iron in the culture medium leads to increases in steady-state levels of oxidative DNA damage. ${ }^{34}$ Previous studies have suggested that iron ions could stimulate a Fenton-like reaction to produce hydroxyl radicals, which mediates DNA strand breakage. ${ }^{35,36}$ We investigated the participation of iron ions in the $\mathrm{H}_{2} \mathrm{O}_{2}$ /ferritin-mediated DNA strand breakages. When DNA reacted with $\mathrm{H}_{2} \mathrm{O}_{2}$ and ferritin in the presence of the iron-specific chelator, deferoxamine, DNA strand breakage was significantly inhibited (Fig. 4). The results indicated that iron ions were involved in the DNA cleavage by

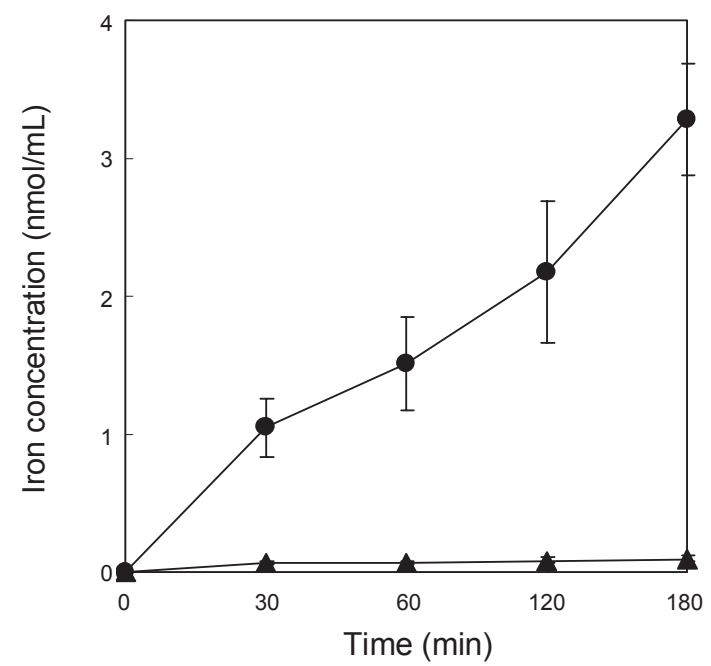

Figure 5. The iron release in the ferritin and $\mathrm{H}_{2} \mathrm{O}_{2}$ system. $1 \mu \mathrm{M}$ Ferritin was incubated with $(\bullet)$ or without $(\boldsymbol{\Delta}) 1 \mathrm{mM} \mathrm{H}_{2} \mathrm{O}_{2}$ in a $10 \mathrm{mM}$ phosphate buffer at $\mathrm{pH}$ 7.4. After incubation, the mixture was then placed into Ultrafree-MC filter and centrifuged at 13,000 rpm for $1 \mathrm{~h}$. The colorimetric reagent was added into the filtrate for analysis by UV-vis spectrophotometry (Shimadzu, UV-1601) at 535nm. The final concentrations of the color reagent were $1 \%$ ascorbate, $0.02 \%$ bathophenanthroline sulfonate and $1 \%$ acetic acid-acetate buffer ( $\mathrm{pH} 4.5)$

the ferritin $/ \mathrm{H}_{2} \mathrm{O}_{2}$ system.

$\mathrm{H}$-ferritin subunits have an active ferroxidase site and occur in multiple forms, in humans, animals, plants and bacteria. L-ferritin subunits have a degenerate ferroxidase site and the gene duplication to encode L-ferritin subunits is found only in vertebrate animals. It was shown that the co-presence of both subunits in hybrids make the molecule more efficient for iron incorporation, because of the combined action of the ferroxidase centers on $\mathrm{H}$-chains and of the effective nucleation centers on L-chains. ${ }^{37} \mathrm{X}$-ray crystallographic data of the mouse L-chain showed that a metal-binding site on the cavity surface, involving residues Glu57, Glu60, Glu61, and Glu64, and in the hydrophilic 3-fold channel involving His118, Glu134, Asp131 and His136 ${ }^{38}$ In the present study, the incubation of $\mathrm{H}_{2} \mathrm{O}_{2}$ and ferritin led to the release of iron from the protein (Fig. 5). Thus, it is suggested that iron binding sites were modified during the reaction of ferritin with $\mathrm{H}_{2} \mathrm{O}_{2}$. Consequently, iron became almost free from the ligand and was released from the oxidatively-damaged protein.

It has been previously reported that the mutagenic spectrum of oxygen free radicals is produced by the aerobic incubation of single-strand M13mp2 DNA with iron. ${ }^{39}$ The biological consequences of DNA damage induced by ferritin $/ \mathrm{H}_{2} \mathrm{O}_{2}$ were investigated. pUC19 plasmid DNA was treated with or without ferritin and $\mathrm{H}_{2} \mathrm{O}_{2}$. Damaged DNA was transfected into $E$. coli (DH5 $\alpha$ ) competent cells, and mutant cells within the nonessential lac $Z \alpha$-gene for $\beta$-galactosidase were identified by decreased $\alpha$-complementation. $E$. col $i$ harboring active $\beta$-galactosidase produces dense blue colonies, whereas mutation within the $l a c Z$ $\alpha$ segment of pUC19 plasmid DNA induced the expression of substantially less active $\beta$-galactosidase and yielded light blue or white colonies. The frequency of mutants obtained with ferritin $/ \mathrm{H}_{2} \mathrm{O}_{2}$ was approximately six-fold greater than that ob- 
Table 1. Mutagenicity of ferritin $/ \mathrm{H}_{2} \mathrm{O}_{2}$ treated pUC19 plasmid in E. coli

\begin{tabular}{lc}
\hline Treatment & $\begin{array}{c}\text { Relative mutation } \\
\text { frequency (fold) }\end{array}$ \\
\hline $\mathrm{pUC19}$ & 1.0 \\
$\mathrm{pUC19}+\mathrm{H}_{2} \mathrm{O}_{2}$ & $1.5 \pm 0.2$ \\
$\mathrm{pUC19}+$ ferritin & $1.9 \pm 0.4$ \\
$\mathrm{pUC19}+$ ferritin $/ \mathrm{H}_{2} \mathrm{O}_{2}$ & $5.9 \pm 0.6$ \\
\hline
\end{tabular}

$\overline{{ }^{a}}$ Mutation frequency was calculated as the ratio between the mutant colonies and total colonies. The results are expressed as a relative mutation frequency and represent the mean \pm S.D. from triplicate measurements.

tained with untreated DNA (Table 1). Our results indicated that a multiplicity of DNA lesions produced by the ferritin $/ \mathrm{H}_{2} \mathrm{O}_{2}$ system in vitro is promutagenic and could be a source of spontaneous mutations.

In conclusion, the present results indicated that DNA cleavage and mutation were induced by the reaction of ferritin with $\mathrm{H}_{2} \mathrm{O}_{2}$ involving hydroxyl radicals that were generated by the Fenton-like reaction. Our study suggested that DNA damage by the ferritin $/ \mathrm{H}_{2} \mathrm{O}_{2}$ system could be relatively favored in diseases where ferritin concentration is elevated.

\section{References}

1. Beard, J. L.; Connor, J. R. Annu. Rev. Nutr. 2003, 23,41.

2. Halliwell, B.; Gutteridge, J. M. C. Free Radicals in Biology and Medicine, 4th ed.; Oxford University Press: UK, 2007.

3. Harrison, P. M.; Arosio, P. Biochim. Biophys. Acta. 1996, 1275 , 161.

4. Theil, E. C.; Matzapetakis, M.; Liu, X. J. Biol. Inorg. Chem. 2006, 11,803 .

5. Theil, E. C. J. Nutr. 2003, 133, S1549.

6. Liu, X.; Theil, E. C. Acc. Chem. Res. 2005, 38, 167.

7. Monterio, H.; Ville, G.; Winterbourn, C. Free Radic. Biol. Med. 1989, 6, 587.

8. Lapenna, D.; de Gioia, S.; Mezzetti, A.; Ciofani, G.; Consoli, A.; Marzio, L.; Cuccurullo, F. Am. J. Respir. Crit. Care Med. 1995, 151,431 .

9. Linert, W.; Herlinger, E.; Jameson, R. F.; Kienzl, E.; Jellinger, K.; Youdim, M. B. Biochim. Biophys. Acta 1996, 1316, 160.
10. Double, K. L.; Maywald, M.; Schmittle, M.; Riederer, P.; Gerlach, M. J. Neurochem. 1998, 70, 2492.

11. Monterio, H.; Winterbourn, C. Biochem. J. 1988, 256, 923.

12. Boyer, R.; Grabill, T.; Petrovich, R. Anal. Biochem. 1988, $174,17$.

13. Halliwell, B.; Gutteridge, J. M. Mol. Aspects Med. 1985, 8, 89.

14. Gotz, M. E.; Kunig, G.; Riderer, P.; Youdim, M. B. Pharmacol. Ther. 1994, 63, 37.

15. Hyslop, P. A.; Zhang, Z.; Pearson, D. V.; Phebus, L. A. Brain Res. 1995, 671, 181.

16. Gius, D.; Spitt, D. R. Antioxid. Redox. Signal. 2006, 8, 1249.

17. Behl, C.; Davis, J. B.; Lesley, R.; Schubert, D. Cell. 1994, 77, 817.

18. Radi, R.; Thomson, L.; Rubbo, H.; Prodanov, E. Arch. Biochem. Biophys. 1991, 288, 112.

19. Childs, R. E.; Bardsley, W. G. Biochem. J. 1975, 145, 93.

20. Pieroni, L.; Khalil, L.; Charlotte, F.; Poynard, T.; Piton, A.; Hainque, B.; Imbert-Bismut, F. Clin. Chem. 2001, 47, 2059.

21. von Sonntag, C. Free-Radical-Induced DNA Damage and Its Repair; Springer: Basle, 2006.

22. Wolfeden, B. S.; Wilson, R. L. J. Chem. Soc. Perkin Trans. II 1982, 805.

23. D’Aquino, M.; Dunster, C.; Wilson, R. L. Biochem. Biophys. Res. Commun. 1989, 161, 1199.

24. Boveries, A.; Oshino, N. Biochem. J. 1972, 128, 617.

25. Imlay, J. A.; Fridovich, I. J. Biol. Chem. 1991, 266, 6957.

26. Turrens, J. F.; Beoni, M.; Brilla, J.; Chavez, U. B.; McCord, J. M. Free. Radic. Res. Comms. 1991, 12, 681.

27. D’Agostino, D. P.; Olson, J. E.; Dean, J. B. Neuroscience 2009 , $159,1011$.

28. Goldstein, S.; Czapski, G. Free Radic. Res. Commun. 1987, 51, 693.

29. Gutteridge, J. M.; Halliwell, B. Biochem. Pharmacol. 1982, 31, 2801.

30. Imlay, J. A.; Chin, S. M.; Linn, S. Science 1988, 240, 640.

31. Prutz, W. A. Radiat. Environ. Biophys. 1984, 23, 7.

32. Kang, J. H. Bull. Korean Chem. Soc. 2006, 27, 1891.

33. Kang, J. H. Bull. Korean Chem. Soc. 2007, 28, 2329.

34. Zastawny, T. H. Free Radic. Biol. Med. 1995, 18, 1013.

35. Tachon, P. Free Radic. Res. Commun. 1989, 7, 1.

36. Tachon, P. Free Radic. Res. Commun. 1990, 9, 39.

37. Santambrogio, P.; Levi, S.; Cozzi, A.; Rovida, E.; Albertini, A.; Arosio, P. J. Biol. Chem. 1993, 268, 12744.

38. Granier, T.; Langlois d'Estainot, B.; Gallois, B.; Chevalier, J. M.; Precigoux, G.; Santambrogio, P.; Arosio, P. J. Biol. Inorg. Chem. 2003, 8, 105.

39. McBride, T. J.; Preston, B. D.; Loeb, L. A. Biochemistry 1991, 30, 207. 